\title{
Insulin-like Growth Factor I Gene Expression in Isolated Rat Renal Collecting Duct Is Stimulated by Epidermal Growth Factor
}

Sharon A. Rogers, Steven B. Miller, and Marc R. Hammerman

Renal and Endocrine Divisions, Departments of Internal Medicine and Cell Biology and Physiology,

Washington University School of Medicine, St. Louis Missouri 63110

\begin{abstract}
The renal collecting duct is a site of insulin-like growth factor I (IGF I) synthesis. Epidermal growth factor (EGF) is also synthesized within the kidney in the thick ascending limb of Henle's loop and the distal tubule. EGF has been shown to regulate IGF I expression in nonrenal tissues. To shed light upon a role of EGF in intrarenal regulation of IGF I gene expression, plasma membranes prepared from collecting ducts isolated from rat kidney and collecting ducts themselves were incubated in the presence and absence of recombinant human EGF (hEGF). hEGF enhanced phospholipase $C$ activity in collecting duct plasma membranes establishing the potential for EGF signal transduction at this site. Inclusion of hEGF in suspensions of collecting ducts increased production of immunoreactive IGF $I$ in a concentration-dependent manner. Production was stimulated significantly by addition of $10^{-8}$ or $10^{-6} \mathrm{M}$ hEGF to suspensions for $2 \mathrm{~h}$. Levels of IGF I mRNA in collecting ducts were increased 2.8 -fold after incubation with $10^{-6} \mathrm{M}$ hEGF in vitro. Our findings demonstrate a direct action of hEGF to enhance collecting duct IGF I gene expression in vitro. Such enhancement is likely to reflect an effect of EGF to stimulate IGF I production in the collecting duct of the intact kidney. Since EGF is produced in kidney, our findings are consistent with intrarenal paracrine regulation of IGF I gene expression by EGF. (J. Clin. Invest. 1991. 87:347-351.) Key words: growth hormone $\bullet$ inositol trisphosphate $\bullet$ phospholipase $C$ • renal hypertrophy • somatomedin
\end{abstract}

\section{Introduction}

The renal collecting duct is a site of insulin-like growth factor I (IGF I) ${ }^{1}$ synthesis. IGF I of kidney origin is thought to regulate

Address reprint requests to Dr. Hammerman, Box 8121, Department of Medicine, Washington University School of Medicine, 660 South Euclid Avenue, St. Louis, MO 63110.

Received for publication 12 July 1990 and in revised form 25 September 1990

1. Abbreviations used in this paper: $\mathrm{EGF}$ and $\mathrm{hEGF}$, epidermal growth factor and recombinant human EGF; GH and bGH, growth hormone and bovine GH; IGF I, insulin-like growth factor I; Ins- $P_{3}$, inositol trisphosphate.

J. Clin. Invest.

(c) The American Society for Clinical Investigation, Inc.

0021-9738/91/01/0347/05 \$2.00

Volume 87, January 1991, 347-351 renal transport, metabolic, and growth processes (1). As in nonrenal tissues, growth hormone (GH) stimulates renal IGF I gene expression. This occurs via a direct action on collecting duct cells (2). The existence of factors other than GH that regulate IGF I gene expression in kidney is demonstrated by the findings of increased renal IGF I production under conditions where GH cannot play a causative role. Two such conditions are compensatory hypertrophy after unilateral nephrectomy (3) and early experimental diabetes mellitus (4-6). The identity of factors other than GH that regulate IGF I expression in these or other states is unknown.

Epidermal growth factor (EGF), like IGF I, is produced in kidney and affects renal transport, metabolism, and growth. The sites of renal EGF synthesis are the thick ascending limb of Henle's loop and the distal convoluted tubule (7). Because it is synthesized in distal portions of the kidney, renal EGF is thought to act upon structures in the collecting duct. The potential for EGF to regulate IGF I expression at this site is provided by the finding that EGF stimulates the production of somatomedin C (IGF I) by cultured human fibroblasts (8). To ascertain whether EGF exerts a similar action in kidney, we performed a series of experiments using collecting ducts isolated from rat kidney: $(a)$ we determined whether EGF "signal" transduction occurs in plasma membranes prepared from collecting ducts; $(b)$ we determined whether EGF stimulates IGF I production in suspensions of collecting ducts; and $(c)$ we determined whether EGF affects levels of IGF I mRNA in these suspensions. Our findings show that EGF acts directly in isolated collecting duct to enhance IGF I gene expression. It is possible that EGF produced in the thick ascending limb of Henle's loop or distal tubule acts directly upon collecting duct in vivo to enhance IGF I production, as part of an intrarenal EGF-IGF I axis. Certain of the actions of EGF on kidney could be mediated by IGF I.

\section{Methods}

Experimental animals and isolation of tissues. Male Sprague-Dawley rats aged $12 \mathrm{wk}$ weighing $\sim 250 \mathrm{~g}$ were used for experiments. Collecting ducts from rat kidneys were isolated using methodology identical to that employed in previous studies (2). In brief, renal medulla was removed from kidneys and placed in ice-cold modified Ringer's solution consisting of $118 \mathrm{mM} \mathrm{NaCl}, 16 \mathrm{mM}$ Hepes, $17 \mathrm{mM} \mathrm{Na}$-Hepes, $14 \mathrm{mM}$ glucose, $3.2 \mathrm{mM} \mathrm{KCl}, 2.5 \mathrm{mM} \mathrm{CaCl}_{2}$, and $1.8 \mathrm{mM} \mathrm{KH}_{2} \mathrm{PO}_{4}$, $\mathrm{pH} 7.4$. The tissue was minced, gassed with room air, and incubated at $37^{\circ} \mathrm{C}$ in $0.2 \%$ collagenase (collagenase D, Boehringer Mannheim Biochemicals, Indianapolis, IN). After $45 \mathrm{~min}, 0.001 \%$ DNAse (type 1, grade II, Boehringer Mannheim Biochemicals) was added to prevent clumping. 
After an additional $45 \mathrm{~min}$, the suspension was centrifuged at $175 \mathrm{~g}$ for $2 \mathrm{~min}$, the supernatant was discarded, and the pellet was resuspended in buffer without DNAse. Centrifugation and resuspension were repeated twice. Plasma membranes were prepared from isolated collecting ducts as described before (9). We have shown that these membranes are enriched for arginine vasopressin-stimulated adenylate cyclase activity, but not for parathyroid hormone-stimulated adenylate cyclase (9).

Measurement of phospholipase $C$ activity. Phospholipase $C$ activity associated with isolated collecting duct membranes was evaluated by measuring levels of inositol trisphosphate $\left(\right.$ Ins- $\left.\mathrm{P}_{3}\right)$ in membrane suspensions as in previous studies (10). Membranes (1 mg of protein) were suspended in $25 \mathrm{mM}$ sucrose, $130 \mathrm{mM} \mathrm{NaCl}, 500 \mu \mathrm{M}$ EGTA, and 50 $\mathrm{mM}$ Tris- $\mathrm{HCl}$. Sufficient $\mathrm{CaCl}_{2}$ was added so that the concentrations of free calcium was $200 \mathrm{nM}$. Suspensions were incubated for $15 \mathrm{~s}$ in the absence of added hormone or in the presence of varying concentrations of recombinant human epidermal growth factor (hEGF) (Upstate Biotechnology Inc., Lake Placid, NY, or Boeringer Mannheim Biochemicals). After incubation, membranes were extracted with $1 \mathrm{ml}$ of chloroform/methanol 2:1 (vol/vol), containing $2.4 \mathrm{M} \mathrm{HCl}$. To measure Ins$\mathrm{P}_{3}$ originating from membranes, water-soluble inositol phosphates contained in the methanol layer of the extraction mixture were separated by high-performance liquid chromatography (HPLC). The Ins- $\mathrm{P}_{3}$ peak was desalted, concentrated, and dephosphorylated, and free myoinositol was measured using an enzymatic fluorometric assay.

Measurement of IGF I in collecting duct suspensions. Isolated collecting ducts $\left(10 \mathrm{mg}\right.$ ) were incubated at $37^{\circ} \mathrm{C}$ for $2 \mathrm{~h}$ in a medium consisting of a 1:1 mixture of Ham's F-12 and Dulbecco's modified Eagle's medium with the following additions: Hepes, $15 \mathrm{mM}$; gentamicin, $50 \mu \mathrm{g} / \mathrm{ml}$; nystatin, $10,000 \mathrm{U} / \mathrm{ml}$; penicillin/streptomycin, $50 \mathrm{U} /$ $\mathrm{ml} ; \mathrm{NaSeO}_{4}, 1.66 \mathrm{mg} / \mathrm{ml}$; and transferrin, $5 \mu \mathrm{g} / \mathrm{ml}$. The mixture was gassed with $95 \% \mathrm{O}_{2} / 5 \% \mathrm{CO}_{2}$ for 30 s before incubation and every 30 min during the incubation. Other additions included varying concentrations of hEGF or bovine growth hormone (bGH) (Monsanto Chemical Co., St. Louis, MO) as indicated. The incubation volume was $5 \mathrm{ml}$. After $2 \mathrm{~h}$ of incubation, suspensions to which hEGF or bGH or no peptide were added were examined microscopically. The appearance of suspensions was as shown (9) and no differences were noted in morphologies of suspensions incubated with hEGF, bGH, or without peptide or in the ability of cells within suspensions to exclude Trypan blue ( $\sim 90 \%$ exclusion). After $2 \mathrm{~h}$, entire suspensions were extracted with $0.2 \mathrm{M}$ acetic acid containing $0.1 \mathrm{M}$ trimethylamine, $\mathrm{pH} 2.8$. The mixture was allowed to incubate at $4^{\circ} \mathrm{C}$ for $2 \mathrm{~h}$. After thorough mixing and centrifugation at $35,000 \mathrm{~g}$ for $20 \mathrm{~min}$, the supernatant was collected and concentrated using a concentrator (Speed-Vac, Savant Instruments, Inc., Hicksville, NY), and samples were resuspended in $0.2 \mathrm{M}$ acetic acid containing $0.1 \mathrm{M}$ trimethylamine, $\mathrm{pH} 2.8$. Samples were injected into a C18 HPLC gel filtration column (TSK G-2000SWXY, Supelco, Inc., Bellefonte, PA) infused with $0.2 \mathrm{M}$ acetic acid, $0.1 \mathrm{M}$ trimethylamine, $\mathrm{pH} 2.8$, with a flow rate of $1 \mathrm{ml} / \mathrm{min}$. This procedure separates IGF I of collecting duct origin from IGF binding activity (2). $1-\mathrm{ml}$ samples were collected, concentrated to dryness, and suspended in $400 \mu 1$ of radioimmunoassay buffer $\left(0.3 \mathrm{M} \mathrm{NaH}_{2} \mathrm{PO}_{4}, 0.01 \mathrm{M}\right.$ EDTA, $0.02 \mathrm{M} \mathrm{NaN}_{3} 1 \%$ bovine serum albumin, $\mathrm{pH}$ 7.6), after which IGF I was measured using a radioimmunoassay as before (2). Polyclonal rabbit anti-human IGF I antiserum was provided through the National Hormone and Pituitary Program by Drs. Louis E. Underwood and Judson J. Van Wyk, University of North Carolina, Chapel Hill, NC.

Measurement of IGF I mRNA in isolated collecting ducts. To collecting ducts suspended in Ham's F12/Dulbecco's modified Eagle's medium as described above, was added $10^{-6} \mathrm{M}$ hEGF, bGH, or no peptide. After $2 \mathrm{~h}$ of incubation at $37^{\circ} \mathrm{C}$, collecting ducts were pelleted by centrifugation. Total cellular RNA was isolated using RNAzol B (Cinna/Biotecx Laboratories, Friendswood, TX). $100 \mu \mathrm{g}$ of collecting duct RNA routinely were isolated from eight kidneys. The integrity of RNA samples was evaluated using agarose/formaldehyde gel chroma- tography and its quantity was determined spectrophotometrically as before $(2,9)$. Solution-hybridization nuclease-protection assays for IGF I or IGF II mRNA were performed as previously described (9). A mRNA probe derived from a subclone of rat IGF I exon 3 or a probe derived from a subclone consisting of most of the first protein-coding exon of rat IGF II and adjacent intron sequences was used in these experiments. A 182 nucleotide portion of the former probe is protected by IGF I mRNA. The protected IGF II fragment appears as a doublet of 151-152 bases (9). The probes were synthesized in an antisense direction as before using T7 (IGF I) or T3 (IGF II) polymerase. Samples were subjected to electrophoresis using $6 \%$ acrylamide/8.3 M urea DNA sequencing gels. After electrophoresis, gels were dried and exposed to XAR film (Eastman Kodak Co., Rochester, NY). In all experiments, rat liver RNA was included as a positive control. RNA quantities were determined by gel scanning as before (2).

Other techniques. Protein was measured as before (11).

\section{Results}

One mechanism by which EGF transmits its "signal" across the plasma membrane of renal collecting duct cells is via activation of phospholipase $C(12)$. To establish that the potential exists for EGF signal transduction across the plasma membrane of isolated rat renal collecting duct cells, membranes prepared from collecting duct segments were incubated for $15 \mathrm{~s}$ in the absence of added peptide or in the presence of $10^{-10}$, $10^{-8}$, or $10^{-6} \mathrm{M}$ hEGF. Levels of Ins- $\mathrm{P}_{3}$ were measured in suspensions after chloroform/methanol extraction. As shown in Fig. 1, addition of $10^{-8}$ or $10^{-6} \mathrm{M}$ hEGF to suspensions resulted in increased Ins- $\mathrm{P}_{3}$ production $(P<0.01$ for each, $n=4$, Dunnett's multiple comparison procedure) (13). Therefore hEGF, like human GH (2), activates phospholipase C in these membranes. In contrast, human prolactin does not activate phospholipase $\mathrm{C}$ at this site (2). The concentration dependence for hEGF-stimulated Ins- $\mathrm{P}_{3}$ production in isolated membranes illustrated in Fig. 1 is similar to that shown by Teitelbaum et al. (12), who reported a significant increase of Ins- $P_{3}$ production upon addition of $10^{-8} \mathrm{M}$ or higher concentrations of EGF to cultured rat inner medullary collecting tubule cells (12).

We have shown previously that GH activates IGF I gene expression via a direct interaction of cells within rat renal collecting duct (2). To determine whether EGF enhances IGF I gene expression at this site, we incubated isolated collecting ducts with or without hEGF and measured IGF I present in whole cellular extracts. Levels of IGF I in suspensions are un-

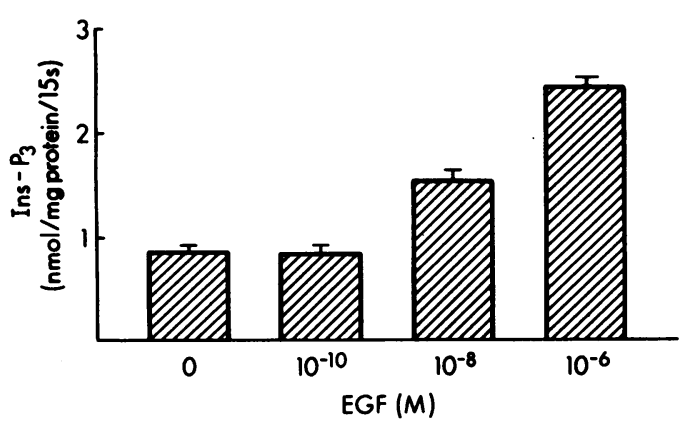

Figure 1. Levels of Ins- $\mathrm{P}^{3}$ in suspensions of rat renal collecting duct plasma membranes. Membranes were incubated in the absence of peptide $(0)$ or in the presence of three concentrations of hEGF. Data represent mean $\pm \mathrm{SE}$ of four separate experiments. 


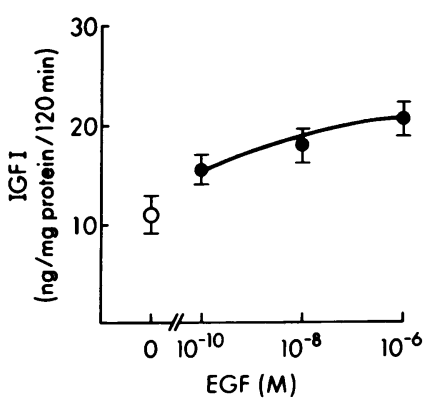

Figure 2. Levels of immunoreactive IGF I in collecting ducts incubated with varying concentrations of hEGF for $2 \mathrm{~h}$. Data are mean $\pm \mathrm{SE}$ of three separate experiments. changed for $2 \mathrm{~h}$ of incubation in the absence of added peptide (2). Addition of hEGF to suspensions of collecting ducts resulted in a concentration-dependent production of IGF I (Fig. 2). Levels of IGF I extractable from suspensions incubated with $10^{-8}(P<0.05)$ and $10^{-6} \mathrm{M}$ hEGF $(P<0.01)$ were significantly elevated compared to levels extractable from suspensions incubated with 0 hEGF ( $n=3$, Dunnett's multiple comparison procedure). These findings demonstrate that hEGF stimulates production of IGF I in isolated rat renal collecting ducts.

To ascertain whether levels of IGF I mRNA are increased by addition of hEGF to collecting ducts in vitro, we extracted total cellular RNA from collecting ducts incubated with or without $10^{-6} \mathrm{M}$ hEGF or bGH and measured IGF I mRNA using a solution-hybridization nuclease protection assay. Fig. 3 illustrates that steady-state levels of IGF I mRNA in these cells are increased by hEGF. Levels of IGF I mRNA in collecting ducts were quantitated by gel scanning. Levels in collecting ducts incubated with hEGF were increased by $2.8 \pm 0.18$-fold ( $P$ $<0.01$, Student's $t$ test, $n=4)$ compared to levels in collecting ducts incubated in the absence of peptide ( $100 \%$, control) (Fig. 4). The increase is comparable to that observed after incubation of collecting ducts with $10^{-6} \mathrm{M}$ bGH (3.0 \pm 0.52 -fold) $(P$ $<0.01$, Student's $t$ test, $n=6$ ) (Fig. 4). These findings and those

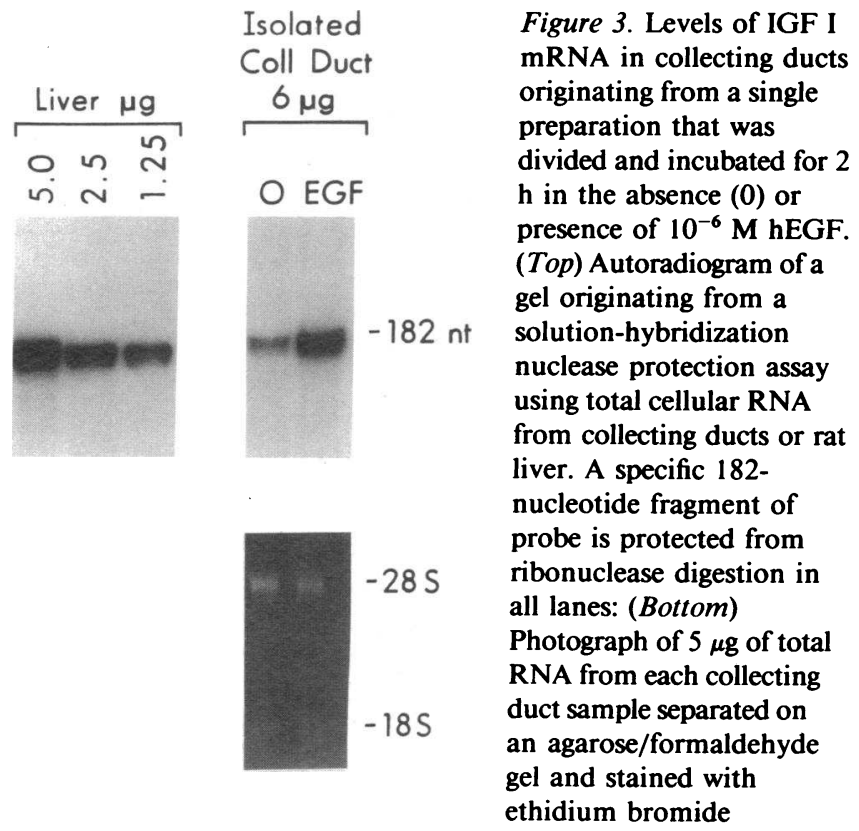

demonstrates that similar amounts of intact RNA were used for each nuclease protection experiment.

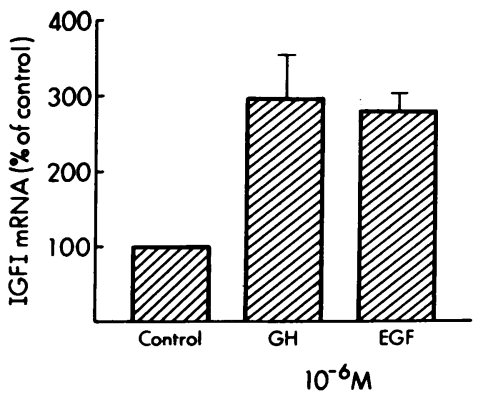

shown in Figs. 2 and 3 demonstrate hEGF stimulation of IGF I gene expression in collecting duct in vitro.

IGF II mRNA is present in small quantities in collecting duct (9). In contrast to the case for IGF I mRNA, no increase in levels of IGF II mRNA were found after incubation of collecting ducts with $10^{-6} \mathrm{M}$ hEGF as determined by gel scanning, $n$ $=3$ experiments (data not shown).

\section{Discussion}

The studies described above represent the first demonstration that EGF stimulates IGF I gene expression in the kidney. We and others have shown previously that GH enhances renal IGF I expression (1-3). IGF I of renal origin is likely to play a causative role for the renal hypertrophy observed in hypersomatotropic states (14). In addition to hypersomatotropism (14), levels of IGF I in whole kidney (3-5) and collecting duct $(15,16)$ are increased in compensatory renal hypertrophy $(3,15,16)$ and in diabetic renal hypertrophy $(4,5)$. The changes in renal IGF I gene expression in compensatory hypertrophy and diabetes cannot be attributed to GH, since renal IGF I is elevated in compensatory hypertrophy in hypophysectomized rats (3) and since levels of circulating $\mathrm{GH}$ are reduced in diabetic rats (6). Therefore, it is likely that stimuli other than GH regulate IGF I gene expression in kidney in one or both of these conditions and in other settings. The identity of such a stimulus/ stimuli is unknown at present. However, our findings establish the potential for EGF to serve in this capacity.

Mature EGF contains 53 amino acids. It is synthesized as a much larger prepro-EGF precursor consisting of $\sim 1,200$ amino acids. The largest quantities of prepro-EGF mRNA in mice and rats are in the submaxillary gland (17). However, it is next most abundant in kidney, and in other species, levels of prepro-EGF mRNA in kidney are higher than in submaxillary gland (18). The site of EGF synthesis in kidney is the thick ascending limb of Henle's loop and distal tubule as evidenced by the co-presence of prepro-EGF mRNA and immunostainable peptide $(7,17)$. EGF in the thick ascending limb of Henle's loop and distal tubule has been localized histochemically to the luminal membrane (7). The peptide is also present in extracellular portions of the medullary interstitium (19). In the mouse submaxillary gland, prepro-EGF is processed intracellularly to the 53-amino acid form of the peptide. In contrast, in kidney cells the precursor accumulates and is not processed to mature EGF $(17,20)$. Prepro-EGF contains a hydrophobic domain that is thought to anchor the protein in the plasma membrane of renal cells such that the bulk of its amino acids including those that constitute mature EGF are on the cell exterior. Cleav- 
age of the extracellular membrane-bound protein by proteases present in the lumen of the nephron or in serum would serve to release EGF and account for the large quantity of the peptide present in urine (7) or in medullary interstitium $(17,20)$.

In view of the sites of renal EGF production, several groups of investigators have proposed that it may serve as a regulator or renal function in collecting duct. Receptors for EGF have been identified in both cultured rat inner medullary collecting duct cells $(12,21)$ and in freshly isolated suspensions (22). Teitelbaum et al. (12) reported that EGF stimulates phospholipase $C$ activity in cultured rat inner medullary collecting tubule cells (12). Harris (21) demonstrated that EGF enhances $\left[{ }^{3} \mathrm{H}\right]$ thymidine incorporation in rapidly growing cultured rat inner medullary collecting duct cells and, in addition, stimulates arachidonic acid release, prostaglandin $\mathrm{E}_{2}$ synthesis, and cAMP accumulation. Breyer et al. (22) described actions of EGF to inhibit vasopressin-stimulated hydraulic conductivity and to depolarize cells in isolated perfused rabbit cortical collecting tubule. These effects were linked to protein kinase $C$ activation and occurred after addition of EGF to the antiluminal, but not to the luminal surface of cells (22). Vehaskari et al. (23) found that EGF decreased $\mathrm{Na}^{+}$reabsorption and reduced lumen-negative transepithelial voltage in isolated perfused rabbit cortical collecting tubules. As was the case in the studies of Breyer et al. (22), EGF added to the luminal surface of cells had no effect (23). The latter findings suggest that EGF released into the tubular lumen of the thick ascending limb of Henle's loop or the distal tubule does not regulate collecting duct function by interacting with luminal membrane receptors. It has been suggested that EGF present in the lumen acts instead as a cytoprotective agent for the uroepithelium (7). However, EGF released across the basolateral membranes of cells in the thick ascending limb of Henle's loop or distal tubule $(17,19)$ could function as a paracrine agent in collecting duct.

Our findings are consistent with the presence of an intrarenal EGF-IGF I axis. A role for this axis in compensatory hypertrophy is suggested by the findings that EGF expression in distal tubule is enhanced in compensatory hypertrophy in rats and mice $(7,24)$, and that the timing of enhanced renal EGF synthesis is similar to the timing of IGF I synthesis (7). EGF could provide the stimulus for IGF I gene expression in this setting.

Insight into the function of EGF and IGF I in recovery from acute ischemic renal failure is provided by several recent observations. Andersson and Jennische (25) demonstrated that IGF I immunoreactivity is expressed by collecting duct cells and by cells invading the region adjacent to damaged proximal tubular cells within days after acute ischemic injury in the rat. Expression of immunoreactivity coincided temporally with postischemic regeneration of proximal tubule. These investigators concluded that there is a transient increase in the expression IGF I confined to the early phase of postischemic kidney regeneration, and that IGF I exerts a trophic role on proximal tubule by paracrine mechanisms (25). Safirstein et al. (26) found reduced renal prepro-EGF mRNA and decreased EGF excretion after induction of ischemic acute renal failure in rats. They suggest that these changes could be a consequence of kidney damage and may reflect the events leading to renal failure or alternatively, and that reduced EGF synthesis is an adaptation permitting restoration of kidney function (26). Support for the former hypothesis is provided by Humes et al. (27) and Norman et al.
(28) who showed that administration of EGF to rats enhances renal tubule cell regeneration and repair and accelerates the recovery of renal function in postischemic acute renal failure. In view of the action of EGF to enhance IGF I gene expression in collecting duct, it is possible that production of endogenous EGF provides a stimulus for IGF I expression during ischemic renal injury. Alternatively, or in addition, the effect of exogenous EGF to hasten recovery after ischemia could be mediated via enhanced production of IGF I.

\section{Acknowledgments}

We are grateful for the typing skills of Ms. Lynn Wesselmann. We thank Dr. Peter Rotwein, Washington University, for supplying rat IGF I cDNA.

S. A. Rogers and M. R. Hammerman were supported by grants DK-27600, DK-42958, and DK-09976 from the National Institutes of Health and by grant 186270 from the Juvenile Diabetes Foundation. S. B. Miller was supported by training grant DK-07120.

\section{References}

1. Hammerman, M. R. 1989. The growth hormone-insulin-like growth factor axis in kidney. Am. J. Physiol. 257:F503-F514.

2. Rogers, S. A., S. B. Miller, and M. R. Hammerman. 1990. Growth hormone stimulates IGF I gene expression in isolated rat renal collecting duct. Am. J. Physiol. 259:F474-F479.

3. Stiles, A. D., I. R. S. Sosenko, A. J. D'Ercole, and B. T. Smith. 1985 Relation of kidney tissue somatomedin C/insulin-like growth factor I to postnephrectomy renal growth in the rat. Endocrinology. 117:2397-2401.

4. Flyvbjerg, A., O. Thorlacius-Ussing, R. Naeraa, J. Ingerslev, and H. Orskov. 1988. Kidney tissue somatomedin $\mathrm{C}$ and initial renal growth in diabetic and uninephrectomized rats. Diabetologia 31:310-314.

5. Bach, L. A., and G. Jerums. 1990. Effect of puberty on initial kidney growth and rise of kidney IGF-I in diabetic rats. Diabetes. 39:557-562.

6. Tannebaum, G. S. 1981 Growth hormone secretory dynamics in streptozotocin diabetes; evidence for a role for endogenous circulating somatostatin. Endocrinology. 108:76-82.

7. Fisher, D. E., E. C. Salido, and L. Barajas. 1989. Epidermal growth factor and the kidney. Annu. Rev. Physiol. 51:67-80.

8. Clemmons, D. R. 1984 . Multiple hormones stimulate the production of somatomedin by cultured human fibroblasts. J. Clin. Endocrinol. Metab. 58:850-856.

9. Bortz, J. D., P. Rotwein, D. DeVol, P. J. Bechtel, V. A. Hansen, and M. R. Hammerman. 1988. Focal expression of insulin-like growth factor $I$ in rat renal collecting duct. J. Cell Biol. 107:811-819.

10. Rogers, S. A., and M. R. Hammerman. 1988. Insulin-like growth factor II stimulates production of inositol trisphosphate in proximal tubular basolateral membranes from canine kidney. Proc. Natl. Acad. Sci. USA. 85:4037-4041.

11. Lowry, O. H., N. J. Rosebrough, A. L. Farr, and J. Randall. 1951. Protein measurement with the Folin phenol reagent. J. Biol. Chem. 193:265-275.

12. Teitelbaum, I., A. Strasheim, and T. Berl. 1990. Epidermal growth factorstimulated phosphoinositide hydrolysis in cultured rat inner medullary collecting tubule cells: regulation by $\mathbf{G}$ protein, calcium and protein kinase C. J. Clin. Invest. 85:1044-1050.

13. Dunnett, C. W. A multiple comparison procedure for comparing several treatments with a control. $1955 \mathrm{~J}$. Am. Stat. Assoc. 50:1096-1121.

14. Miller, S. B., P. Rotwein, J. D. Bortz, P. J. Bechtel, V. A. Hansen, S. A. Rogers, and M. R. Hammerman. 1990. Renal expression of IGF I in hypersomatotropic states. Am. J. Physiol. 259:F251-F257.

15. Lajara, R., P. Rotwein, J. D. Bortz, V. A. Hansen, J. L. Sadow, C. R. Betts, S. A. Rogers, and M. R. Hammerman. Dual regulation of insulin-like growth factor I expression during renal hypertrophy. 1989. Am. J. Physiol. 257:F252 . F261.

16. Andersson, G. L., A. Skottner, and E. Jennische. 1988. Immunocytochemical and biochemical localization of insulin-like growth factor $I$ in the kidney of rats before and after uninephrectomy. Acta Endocrinol. 119:555-560.

17. Rall, L. B., J. Scott, and G. I. Bell 1985. Mouse prepro-epidermal growth factor synthesis by kidney and other tissues. Nature (Lond.). 313:228-231.

18. Bell, G. I., N. M. Fong, M. M. Stemoien, M. A. Wormsted, D. Caput, L. Ku, M. S. Urdea, L. B. Rall, and R. Sanchez-Pescador. 1989. Human epidermal 
growth factor precursor cDNA sequence, expression in vitro and gene organization. Nucleic Acids Res. 14:8427-8446.

19. Kasselberg, A. G., D. N. Orth, M. E. Gray, and M. T. Stahlman. 1985. Immunocytochemical localization of human epidermal growth factor/urogastrone in several human tissues. J. Histochem. Cytochem. 33:315-322.

20. Carpenter, G., and S. Cohen. 1990. Epidermal growth factor. J. Biol. Chem. 265:7709-7712.

21. Harris, R. C. 1989. Response of rat inner medullary collecting duct to epidermal growth factor. Am. J. Physiol. 256:F1117-F1124.

22. Breyer, M. D., H. R. Jacobson, and J. A. Breyer. 1988. Epidermal growth factor inhibits the hydroosmotic effect of vasopressin in the isolated perfused rabbit cortical collecting tubule. J. Clin. Invest. 82:1313-1320.

23. Vehaskari, V. M., K. S. Herring-Smith, D. W. Moskowitz, I. D. Weiner, and L. L. Hamm. 1989. Effect of epidermal growth factor on sodium transport in the cortical collecting tubule. Am. J. Physiol. 256:F803-F809.

24. Jennische, E., G. Andersson, and H. A. Hansson. 1987. Epidermal growth factor is expressed by cells in the distal tubules during postnephrectomy renal growth. Acta Physiol. Scand. 129:449-450.

25. Andersson, G., and E. Jennische. 1988. IGF-I immunoreactivity is expressed by regenerating renal tubular cells after ischemic injury in the rat. Acto Physiol. Scand. 132:453-457.

26. Safirstein, R., A. Z. Zelent, and P. M. Price. 1989. Renal preproepiderma growth factor mRNA and decreased EGF excretion in ARF. Kidney Int. 36:810815 .

27. Humes, H. D., D. A. Cieslinski, T. M. Coimbra, J. M. Messana, and C. Galvao. 1989. Epidermal growth factor enhances renal tubule cell regeneration and repair and accelerates the recovery of renal function in postischemic renal failure. J. Clin. Invest. 84:1757-1761.

28. Norman, J., Y. K. Tsau. A. Bacay, and L. G. Fine. 1990. Epidermal growth factor accelerates functional recovery from ischaemic acute tubular necrosis in the rat: role of the epidermal growth factor receptor. Clin. Sci. 78:445450. 